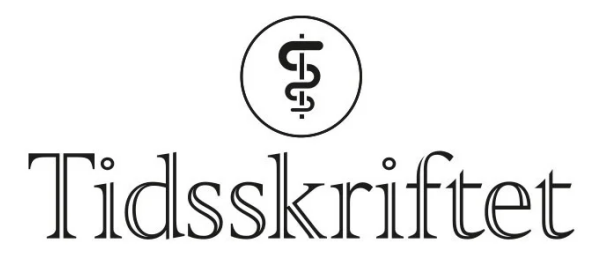

DEN NORSKE LEGEFORENING

\title{
Ett försök till kompletterande perspektiv på coronaviruset
}

LEGELIVET

\section{FREDRIK BÅÅTHE}

fredrik.baathe@legeforeningen.no

LEFO - Legeforskningsinstituttet

Eftersom många av oss dagligen tar del av medias rapportering från utvecklingen av covid-19-pandemin, kanske några kompletterande perspektiv kan vara meningsfullt.

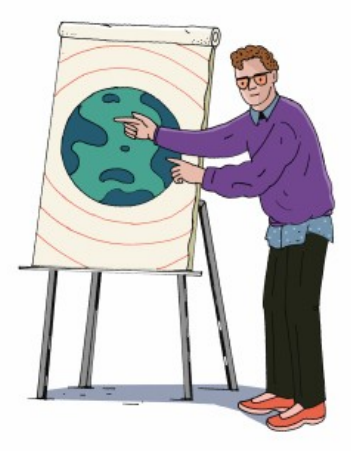

Illustrasjon: Maxim Usik /

NTB Scanpix

11. mars signalerar WHO en covid-19-pandemi. Samma dag dör den första svenska patienten och dagen efter dör den första norska patienten på grund av coronaviruset.

På kort tid har många av de saker som vi tar för givet i våra vardagsliv förändrats.

Grundläggande behov såsom mat, sociala relationer och fri rörlighet har utmanats. Olika åtgärder har genomförts för att reducera smittspridningen. Befolkningen har slutit upp runt begreppet "platta ut kurvan» och vägen dit har huvudsakligen handlat om begreppen «social distansering» och "god handhygien».

Går man tillbaks hundra år i tiden till spanska sjukan (1918-20), hittar man liknande kraftfulla samhällsåtgärder som idag. Analyser av de åtgärder som då gjordes för att begränsa spridningen i amerikanska städer visar att det också handlade om social 
distansering, stänga ner allmänna tillställningar och karantän av de som drabbats (1). Hur snabbt man agerade i de olika städerna relaterade till andelen som dog. Städerna agerade också olika när man upplevde att man hade fått kontroll på smittspridningen (르). Skillnad i städernas dödstal visar hur viktigt det var - är - att långsamt och stegvis minska restriktionerna för att reducera risken att en andra våg blir värre än den första. Tänkvärt är att åtgärderna för hundra år sedan är närmast identiska med de åtgärder som lyfts fram i den aktuella rapporten från Imperial College COVID-19 Response Team (3).

Att följa de dagliga nyheterna har blivit ett sätt att själv försöka förstå den pågående utvecklingen och få del av de senaste nationella besluten och rekommendationerna. Nyheterna rapporterar dagligen om antal smittade och döda i covid-19. Detta upplevdes naturligt till en början, men över tid blir det kanske alltmer viktigt att sätta de tal som rapporteras i perspektiv, utan att förminska hotet.

Ett norskt forskarteam har jämfört överdödlighet i säsongsinfluensa med dödlighet i corona mellan Sverige, Danmark och Norge. De argumenterar att vi må minnas att säsongsinfluensa årligen kräver många liv och presenterar antal dödsfall i «normal» säsongsinfluensa, räknat som genomsnitt från de senaste fyra åren; Norge 21 döda per dag, Danmark 23 döda per dag och Sverige 53 döda per dag. De konkluderar att alla tre länderna visar lägre dödlighet från covid-19 jämfört med genomsnittlig dödlighet från säsongsinfluensa (4).

Ett annat tänkvärt perspektiv kan vara hur vi i vår del av världen är förskonade från flera av de dödliga farsoter som ännu drabbar stora delar av världen. Tuberkulos (TBC) kräver årligen 1,3 miljoner dödsoffer (3500 döda per dag) och diarré (symptom på en infektion i mag-tarm-kanalen som uppstår genom virus, bakterier, parasiter och andra mikroorganismer) leder till att 1,4 miljoner människor dör årligen (3 8oo döda per dag) (5).

När vi dagligen tar del av de senaste dödstalen i coronapandemin, kan det vara värdefullt att sätta dem i relation till andra tal, både nationellt och internationellt. Kompletterande perspektiv kan vara meningsfullt i den ovanliga situation vi alla just nu befinner oss i.

\section{LITTERATUR}

1. Morse SS. Pandemic influenza: studying the lessons of history. Proc Natl Acad Sci U S A 2007; 104: 7313-4. [PubMed][CrossRef]

2. Strochlic N, Champine RD. How some cities 'flattened the curve' during the 1918 flu pandemic. National Geographic 27.3.2020. https://www.nationalgeographic.com/history/2020/o3/how-citiesflattened-curve-1918-spanish-flu-pandemic-coronavirus/ Lest 21.4.2020.

3. Ferguson N, Laydon D, Nedjati-Gilani G et al. Impact of non-pharmaceutical interventions (NPIs) to reduce COVID-19 mortality and healthcare demand. London: Imperial College COVID-19 Response Team, 2020. https://www.imperial.ac.uk/media/imperial-college/medicine/sph/ide/gidafellowships/Imperial-College-COVID19-NPI-modelling-16-03-2020.pdf Lest 21.4.2020.

4. Bentzrød SB, Dommerud T. Åtte forskere: Influensa tar flere liv enn koronaviruset i Norge, Sverige og Danmark. Aftenposten 10.4.2020. https://www.aftenposten.no/norge/i/rARmgA/aatte-forskereinfluensa-tar-flere-liv-enn-koronaviruset-i-norge-sverige-og-danmark Lest 21.4.2020.

5. World Health Organization. Top 10 causes of death. https://www.who.int/gho/mortality_burden_disease/causes_death/top_10/en/Lest 21.4.2020.

Publisert: 5. mai 2020. Tidsskr Nor Legeforen. DOI:10.4045/tidsskr.20.0357

(C) Tidsskrift for Den norske legeforening 2023. Lastet ned fra tidsskriftet.no 26. april 2023. 